\title{
The impacts of green infrastructure on air quality and temperature
}

Book or Report Section

Accepted Version

Tallis, M. J., Amorim, J. H., Calfapietra, C., Freer-Smith, P. H., Grimmond, S., Kotthaus, S., Lemes de Oliveira, F., Miranda, A. I. and Toscano, P. (2015) The impacts of green infrastructure on air quality and temperature. In: Sinnett, D., Smith, N. and Burgess, S. (eds.) Handbook on Green Infrastructure: Planning, Design and Implementation. Edward Elgar Publishing, Cheltenham, pp. 30-49. ISBN 9781783473991 Available at http://centaur.reading.ac.uk/52357/

It is advisable to refer to the publisher's version if you intend to cite from the work. See Guidance on citing.

Publisher: Edward Elgar Publishing 
including copyright law. Copyright and IPR is retained by the creators or other copyright holders. Terms and conditions for use of this material are defined in the End User Agreement.

\section{www.reading.ac.uk/centaur}

\section{CentAUR}

Central Archive at the University of Reading

Reading's research outputs online 
Tallis MJ, Amorim JH, Calfapietra C, Freer-Smith PH, Grimmond CSB, Kotthaus S, Lemes de Oliveira F, Miranda AI, Toscano P The impacts of green infrastructure on air quality and temperature Handbook on Green Infrastructure: Planning, design and implementation Ed. D Sinnett, $N$ Smith, S Burgess, Chapter 2, 30-49, ISBN: 9781783473991 http://www.e-elgar.com/shop/handbook-on-green-infrastructure

\section{The impacts of green infrastructure on air quality and temperature} Matthew J. Tallis, Jorge Humberto Amorim, Carlo Calfapietra, Peter Freer-Smith, Sue Grimmond, Simone Kotthaus, Fabiano Lemes de Oliveira, Ana Isabel Miranda, Piero Toscano

\section{AIR QUALITY AND THE URBAN ENVIRONMENT}

Clean air is considered to be a basic requirement for human health and well-being (WHO, 2006), nevertheless, many regions, especially urban, experience high levels of air pollution (Zhu et al., 2013). The World Health Organization (WHO) estimates that outdoor air pollution caused 3.7 million premature deaths (6.7 per cent of total deaths) globally in 2012 (WHO, 2014) resulting from increases in cardiovascular and respiratory disease and cancer. Outdoor air pollution consists of a complex mixture of substances. In urban environments, the pollutants present and their concentrations vary substantially over space and time depending on those factors that control inputs; these include the number and strength of pollution emission sources and atmospheric conditions, and those that affect rates of removal from the atmosphere, particularly climate and the type and form of urban infrastructure. In this respect, vegetation has been identified as an effective form of urban infrastructure (green infrastructure) to reduce urban air pollution. The adverse health outcomes associated with air pollution have a large financial burden. For example, the United Nations Environment Programme (UNEP) has estimated urban air pollution costs approximately 2 per cent of GDP in developed countries and 5 per cent in developing countries. In the United Kingdom, urban air pollution is estimated to be responsible for between 35000 and 50000 premature deaths annually (House of Commons, 2010) and the economic cost of the health burden is estimated to be around $£ 15$ billion (DEFRA, 2010). Air pollution also has wide-ranging environmental impacts, including loss of biodiversity, reduced crop yields and it contributes to climate change.

A number of organizations have set limits for atmospheric pollution concentrations considered as standards for air quality; these include the WHO, the European Union and national agencies such as the US Environmental Protection Agency. The WHO guidelines set atmospheric concentration limits for particulate matter $(\mathrm{PM})$, ozone $\left(\mathrm{O}_{3}\right)$, nitrogen dioxide $\left(\mathrm{NO}_{2}\right)$ and sulphur dioxide $\left(\mathrm{SO}_{2}\right)$. In an assessment of 26 global mega- cities, 24 had annual average $\mathrm{PM}_{10}$ (particulate matter with a mean aerodynamic diameter \#10 mm) concentrations in excess of the levels set in these guidelines (Zhu et al., 2013). The European Commission's Air Quality Standards (CEC, 2008) cover these four pollutants and set standards of atmospheric concentrations for lead $(\mathrm{Pb})$, carbon monoxide $(\mathrm{CO})$, benzene $\left(\mathrm{C}_{6} \mathrm{H}_{6}\right)$, arsenic (As), cadmium $(\mathrm{Cd})$, nickel $(\mathrm{Ni})$ and polycyclic aromatic hydrocarbons (PAH). These represent most atmospheric pollutants in the urban environment.

In terms of adverse health impacts $\mathrm{PM}_{10}$ and, more recently, $\mathrm{PM}_{2.5}$ (particulate matter with a mean aerodynamic diameter $\# 2.5 \mathrm{~mm}$ ) have been identified as the most significant; globally accounting for 3 per cent of cardiopulmonary and 5 per cent of lung cancer deaths (WHO, 2013). Road traffic is one of the main sources of urban pollution (exhaust emissions, brake and tyre wear, and road surface abrasion) and associated ill health (Kim et al., 2008) and road-traffic derived pollutants are most concentrated within tens of metres from the road source (Beevers et al., 2013). In 2005 approximately 200000 deaths in the USA were attributed to air pollution associated with combustion emissions; the majority of which were associated with road traffic derived $\mathrm{PM}_{2.5}$ pollution (Caiazzo et al., 2013). In addition to road traffic, anthropogenic emissions can have a point source origin, for example, arising from energy generation, waste management and industrial activities, and natural sources of air pollution include dust 
Tallis MJ, Amorim JH, Calfapietra C, Freer-Smith PH, Grimmond CSB, Kotthaus S, Lemes de Oliveira F, Miranda AI, Toscano P The impacts of green infrastructure on air quality and temperature Handbook on Green Infrastructure: Planning, design and implementation Ed. D Sinnett, $N$ Smith, S Burgess, Chapter 2, 30-49, ISBN: 9781783473991 http://www.e-elgar.com/shop/handbook-on-green-infrastructure

from soil, volcanic emissions, lightning, windblown seawater and emissions from vegetation. Nevertheless, effective use of vegetation can offer substantial benefits to urban air quality; this is not a new concept, but it has risen to prominence again in recent years.

This chapter begins with a brief look at the historical legacy of using greening for urban air quality improvement. The chapter then looks at the current state of knowledge concerning:

1. Urban vegetation used for urban air quality improvement. A particular focus of this section is the removal of atmospheric PM by vegetation, as this form of urban pollution has been identified as having serious health consequences.

2. Urban vegetation used for climate change mitigation. Here we consider the potential contribution urban vegetation can make towards reducing atmospheric concentrations of the greenhouse gas carbon dioxide.

3. Urban vegetation used to manage the effects of increasing urban temperatures. Here we look at examples of how vegetation can be used to regulate urban temperature, so maintaining a more thermally comfortable urban environment.

\section{A BRIEF HISTORY OF PLANNING OF URBAN GREENING FOR AIR QUALITY IMPROVEMENT}

The establishment of urban green space to improve air quality is not a new phenomenon. Green-s pace planning and pollution have an intertwined history. The industrial revolution brought about significant changes to towns and cities, for example in Europe and the United States (Chadwick, 1966; Cherry, 1974). Air pollution, overcrowding, urban sprawl and lack of open spaces generated severe public health problems (Ashworth, 1954; Sutcliffe, 1981). The creation of public parks emerged as a reaction to unhealthy urban environments by providing fresh air, sunlight and space for recreation in the inner parts of the urban fabric. The creation of the Central Park in New York (1857), Cerdà's plan for Barcelona (1858), the construction of the Ringstrasse in Vienna and Haussmann's transformation of Paris are examples of using greenery to positively transform industrial cities. In the 1830s Chicago's government adopted the phrase Urbs in horto, meaning 'City in a Garden'. Over a century and a half later the first city-w ide assessment concerning the impacts of green infrastructure (in this case the urban tree canopy) on air quality and temperature was carried out in Chicago (McPherson et al., 1994). The formulation of the idea of a citywide comprehensive system of interlinked green spaces has its origins in the work of Frederick Law Olmsted and Calvert Vaux in the United States, which included the plan for Buffalo (1868-69) and Boston (1894). The park system's functions were to articulate the distinct open-s pace typologies, providing green space for the citizens and enhancing health in urban spaces (see Chapter 1). Some green-s pace typologies, such as green wedges, for example, in Harlow, UK (see Lemes de Oliveira, 2014), have been incorporated into urban planning strategies to combat urban air pollution. The idea of a park system spread rapidly in the United States, and in Europe, particularly in Germany and England, the latter including, for example, Letchworth and Welwyn Garden City. Ebenezer Howard's (1898) garden city movement significantly contributed to the creation of a new typology of urban development that aimed to combine the benefits of living in the countryside, such as clean air, with those of living in towns, such as job opportunities. Green infrastructure today is understood as a network of interlinked open green spaces, including a variety of uses and typologies (Benedict et al., 2006) providing ecosystem services (see Chapter 4) such as air pollution management and temperature regulation (Escobedo et al., 2011). 
Tallis MJ, Amorim JH, Calfapietra C, Freer-Smith PH, Grimmond CSB, Kotthaus S, Lemes de Oliveira F, Miranda AI, Toscano P The impacts of green infrastructure on air quality and temperature Handbook on Green Infrastructure: Planning, design and implementation Ed. D Sinnett, $N$ Smith, S Burgess, Chapter 2, 30-49, ISBN: 9781783473991 http://www.e-elgar.com/shop/handbook-on-green-infrastructure

\section{URBAN VEGETATION USED FOR URBAN AIR QUALITY MANAGEMENT}

The interactions among emission sources, atmospheric chemistry and local climate influence the nature and transport of atmospheric pollutants. This will subsequently influence the deposition (atmospheric removal rate), re-suspension and transport of the pollutant through the green space, water and soils. These processes need to be understood and quantified in order to establish the most effective greening solution for a particular pollution scenario. A computer modelling study by Nowak et al. (2006) estimated that the urban tree canopy of 55 cities in the USA removes 711000 tonnes of pollution annually ( $\mathrm{PM}, \mathrm{O}_{3}, \mathrm{NO}_{2}, \mathrm{SO}_{2}$ and $\mathrm{CO}$ ): an average of 10.8 grams of atmospheric pollution removed annually for each $\mathrm{m}^{2}$ of urban tree canopy cover. Recent measurements suggest that the improvement of air quality (particularly the reduction of PM) by urban vegetation may well be substantially more. For example, street trees in front of a sample of terraced houses were shown to reduce indoor pollution by approximately 50 per cent compared with houses with no street trees (Maher et al., 2013) and a 60 per cent reduction was estimated using a model that simulated pollution flow in a tree-lined street canyon (Pugh et al., 2012). It is generally considered that the larger the area of green space (for example, Nowak et al., 2006; Tallis et al., 2011) and the closer the vegetation is to the pollutant source (for example, Peachey et al., 2009; Tallis et al., 2011; Weber et al., 2014) then the greater the benefit is to air quality through pollution removal by vegetation.

The next sub-section provides details on the mechanism for air pollution removal for some typical urban air pollutants, followed by examples of street tree-planting to reduce human exposure to PM. However, vegetation can also contribute to air pollution (an ecosystem disservice) through the emission of biological pollutants such as biologically derived volatile organic compounds (BVOCs), pollen and fungal spores, and pollen- allergic asthma patients can experience enhanced symptoms in the presence of air pollutants such as $\mathrm{PM}, \mathrm{SO}_{2}$ and $\mathrm{NO}_{2}$ (Brito et al., 2007). The final sub-section provides more detail on $\mathrm{BVOC}$ emissions by urban vegetation.

\section{The Mechanisms for the Deposition of Typical Urban Air Pollutants to Vegetation}

Removal of pollutants from the atmosphere occurs through a combination of processes, which are most often separated into dry and wet deposition (see Box 2.1) based upon how the pollutant is transferred from the atmosphere to a structure (for example, vegetation, water, asphalt, brick or concrete surface). The structure influences the amount of atmospheric pollution in the following ways:

- short- term removal, that is, the pollutant can be re-suspended back to the atmosphere when conditions are appropriate;

- longer- term removal, the pollutant is incorporated into the structure (sequestration); and

- The pollutant is transferred to a different medium that is, washed off the structure to reside in soil or hydrological systems.

Longer- term removal and transfer can be considered complementary; for example, pollutants embedded on leaf surfaces and in leaf surface waxes have been removed from the atmosphere and will reside in the soil following leaf fall. Figure 2.1 gives an example of a leaf surface showing particulate deposits. Rough surfaces such as vegetation canopies are more effective than smoother surfaces such as hard urban infrastructure (for example, glass, asphalt, concrete and rock) for pollution removal through dry deposition (Pryor et al., 2007; Roupsard et al., 2013). Trees are considered more effective than shorter vegetation, as a result of their large leaf area, surface roughness and the air turbulence created in their 
Tallis MJ, Amorim JH, Calfapietra C, Freer-Smith PH, Grimmond CSB, Kotthaus S, Lemes de Oliveira F, Miranda AI, Toscano P The impacts of green infrastructure on air quality and temperature Handbook on Green Infrastructure: Planning, design and implementation Ed. D Sinnett, $N$ Smith, S Burgess, Chapter 2, 30-49, ISBN: 9781783473991 http://www.e-elgar.com/shop/handbook-on-green-infrastructure

canopies (Fowler et al., 1989) and large trees are more effective than small ones (Nowak et al., 2002). Nevertheless, grasses and herbaceous vegetation can supplement the benefits of trees because (where appropriate) such vegetation can be planted extensively on road-s ides with foliage situated closer to the road surface and the exhaust emission source (Peachey et al., 2009; Weber et al., 2014). In addition, the stabilization of heavy metals and organic pollutants in vegetation and soils can decrease their impact on water sources and soil micro-organisms so restricting the potential spread and damage from these pollutants (for example, Fantozzi et al., 2013).

\section{Influence of Street Trees and Pollution Exposure to Humans}

The direct link between the role of trees in improving local air quality and the exposure of individuals to air pollution has scarcely been investigated in the scientific literature. Personal exposure to traffic-e mitted $\mathrm{PM}_{10}$ of four hypothetical children was simulated by Amorim et al. (2013b, 2013c) with a computational fluid dynamics (CFD) model. A typical school morning (from 0830 to 1330) was considered, including both contribution from outdoor (during the walk to school) and indoor (inside the classroom) exposure. According to the modelled results, the outdoor exposure to $\mathrm{PM}_{10}$ shows significant distinctions between routes. Children walking along and traversing the main avenue received significantly greater exposure values as a result of the close proximity to the emission source (road

\section{BOX 2.1 Definitions Of Key Terms}

Wet deposition of pollutants: Wet deposition tends to remove pollutants from higher in the atmosphere and, because precipitation occurs for a relatively short proportion of the time, is episodic in many countries. Wet deposition in mist, fog and aerosols is greater in vegetation than in the built environment because the structure of vegetation, particularly trees, is highly efficient at intercepting mist and fog (Freer- Smith et al., 2005), whereas rain and snow inputs tend to be similar to both green space and to urban roads and buildings. Wet deposition tends to account for a smaller amount of pollutant input in comparison with dry deposition. Dry deposition of pollutants: Dry deposition includes both gas and particle transfer to surfaces, and operates continuously at the boundary between the atmosphere and surfaces. Thus, dry deposition is the main mechanism accounting for the increased removal of pollutants by green infrastructure and the associated improvements in urban air quality. Dry deposition on a surface occurs through a number of processes; these include, (1) Brownian motion causing diffusion along a concentration gradient, that is, movement from a high concentration in the atmosphere to a lower concentration of the surface, (2) settling out of the atmosphere (sedimentation under gravity) and (3) direct impaction on a surface and interception by a surface. The rate at which pollution will be transferred from the atmosphere to a removal surface depends upon the size, mass and concentration of the pollutant, the nature of the turbulence transporting the pollutants in the atmosphere and the size, shape, form and 'stickiness' of the surface receiving the pollutants. In Figure 2.1 a highly magnified surface of a commonly planted urban tree, the London Plane (Platanus $x$ acerifolia), can be seen with associated surface pollutant particles. These particles totalled an average mass of $12.7 \mathrm{mg}$ for each $\mathrm{cm}^{2}$ of leaf surface at the time of sampling (October 2014). Particulate matter of size fractions $\mathrm{PM}_{10}$ and $\mathrm{PM}_{2.5}$ are more readily deposited to urban vegetation than particles in the size range 1.0 to $0.1 \mathrm{~mm}\left(\mathrm{PM}_{1.0}\right.$ to $\left.\mathrm{PM}_{0.1}\right)$ (Lovett, 1994; Pryor et al., 2008). These smaller pollutants are examples of trans-boundary pollutants (for example, sulphur and nitrogen containing aerosols such as $\mathrm{SO}_{2}$ responsible for acid rain and $\mathrm{NH}_{4}$ responsible for eutrophication) and the UNECE Convention on Long- range Transboundary Air Pollution covers these. Deposition velocity: The factor linking the rate of pollution dry deposition, or flux $(F)$, with the concentration of pollution $(\mathrm{C})$ in the atmosphere is a term called deposition velocity (Vd) (Hicks et al., 1987) (Equation 1.1). Dry deposition flux (F) increases with both a larger pollutant concentration (C) and an increase in deposition velocity $(\mathrm{Vd})$. Deposition velocity changes according to the surface characteristics (for example, leaf form, and canopy and bark/stem forms), the nature of the pollutant and the local climate acting on both the pollutant and the surface.

$$
\mathrm{F} 5 \mathrm{C}^{*} \mathrm{Vd}(1.1)
$$

In the absence of directly measuring the pollution removed by green surfaces and the benefits of this to air quality, which is practically and technically demanding even for small areas; then, understanding the Vd of the surface for 
Tallis MJ, Amorim JH, Calfapietra C, Freer-Smith PH, Grimmond CSB, Kotthaus S, Lemes de Oliveira F, Miranda AI, Toscano P The impacts of green infrastructure on air quality and temperature Handbook on Green Infrastructure: Planning, design and implementation Ed. D Sinnett, $N$ Smith, S Burgess, Chapter 2, 30-49, ISBN: 9781783473991 http://www.e-elgar.com/shop/handbook-on-green-infrastructure

a range of pollutants and meteorological conditions can allow predictions of the pollution removal rate of that surface. While Vd represents the speed of removal (deposition velocity), its inverse, or opposite term, represents the resistance to pollutant removal $(R)$ from the atmosphere to the surface. In the case of green infrastructure these resistances are determined by (i) the aerodynamic resistance of the pollutant to atmospheric transport $\left(R_{a}\right)$ (ii) the resistance to diffusion across the surface boundary layer (a quasi- laminar flow layer immediately surrounding the leaf) $\left(R_{b}\right)$ and the resistance from the surface itself $\left(R_{c}\right)$. Such that Vd is the inverse of these properties (Equation 1.2)

$$
\operatorname{Vd} 5\left(R_{\mathrm{a}} 1 \mathrm{R}_{\mathrm{b}} 1 \mathrm{R}_{\mathrm{c}}\right)^{-1}
$$

In many cases this resistance is largely determined by the leaf surface properties that determine 'stickiness' for the pollutant (for example, ridges, waxes and hairs) and the canopy properties that determine the wind turbulence (e.g. wind speed, canopy height and aerodynamic roughness). For gases (for example, $\mathrm{CO}_{2}, \mathrm{NO}_{2}, \mathrm{O}_{3}$ and $\mathrm{SO}_{2}$ ) the resistance to deposition is further determined by the rate of uptake through the leaf stomata (stomatal resistance). The amount of stomatal resistance will be influenced by factors that influence stomatal resistance such as plant water availability, light intensity and temperature. Therefore, species-s pecific $\mathrm{Vd}$ can change rapidly throughout a day, with changes in wind speed and direction in the case of PM, and with changes in light intensity, water availability and temperature for gaseous pollutants. In summary, the type of pollutant, the species of vegetation, the positioning of the vegetation in relation to the pollutant source, and the local climate all influence the mechanisms concerning both the rate of removal and total removal of atmospheric pollution by vegetation.

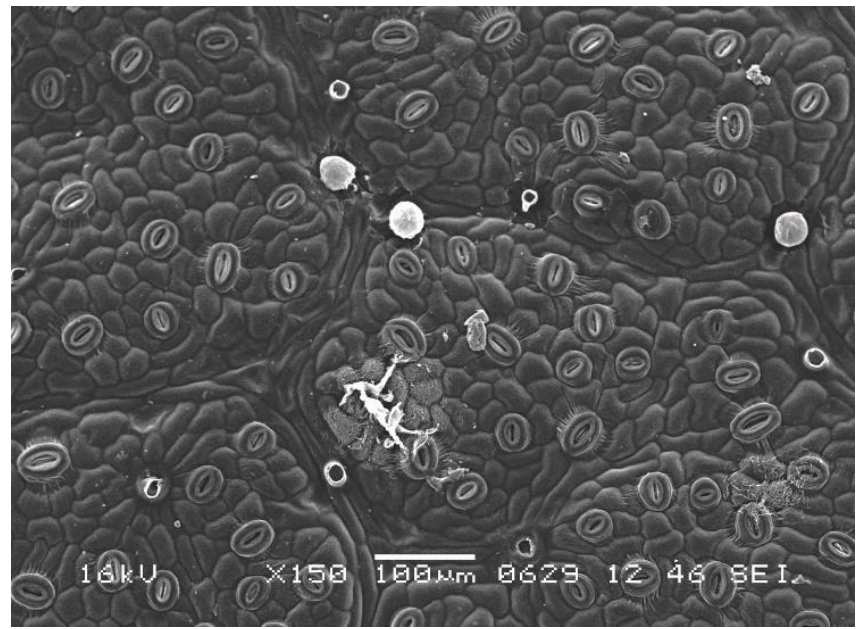

Figure 2.1 A scanning electron microscope image showing the surface of a typical urban street tree leaf, London Plane (Platanus $x$ hispanica) collected from an urban park in Portsmouth, UK. The stomata and deposits of particulate matter can be seen on this leaf surface. The particulate matter residing on the leaf surface was quantified to average $12.7 \mathrm{mg}$ of particulate matter for each $\mathrm{cm}^{2}$ of leaf surface. This amount is similar to the range in mass of particulate matter deposited to leaves from a variety of deciduous broadleaved species (10-20 mg cm$\left.{ }^{-2}\right)$ measured in a study by Sabo et al. (2012). Source: Image from the University of Portsmouth

traffic), than those following routes with less passing traffic. However, a consistent decrease (average 46 per cent) in the mean outdoor exposure to pollution occurred because of the roadside trees. The peak exposure values were also reduced, except for one of the routes. When analysing the indoor exposure levels (the children were located in different classrooms), a benefit from the presence of trees was obtained for three of the children indicating a general decrease in the mean exposure, although this was not consistent for all the four hypothetical children considered. This effect was attributed to the windbreak action induced by trees in the sidewalks of the main avenue, causing a disruption in the transport of traffic- generated particles into the school. From the perspective of human health assessment, the spatial variability of the modelling results suggest that highly targeted tree-planting could yield significant benefits in reducing the exposure of the individuals to pollutants in specific microenvironments. In this sense, modelling exposure studies can be of great importance in planning and design of new green areas, particularly in the case of buildings, that house vulnerable members of the population for prolonged periods (for example, schools and hospitals). This would support an enhanced understanding of the interactions between the outdoor urban morphology, human 
Tallis MJ, Amorim JH, Calfapietra C, Freer-Smith PH, Grimmond CSB, Kotthaus S, Lemes de Oliveira F, Miranda AI, Toscano P The impacts of green infrastructure on air quality and temperature Handbook on Green Infrastructure: Planning, design and implementation Ed. D Sinnett, $N$ Smith, S Burgess, Chapter 2, 30-49, ISBN: 9781783473991 http://www.e-elgar.com/shop/handbook-on-green-infrastructure

dynamics and the indoor environment. For example, a recent study by Maher et al. (2013) showed the direct link between the presence of street trees and nearby indoor air pollution; where silver birch (Betulautilis Doorenbos) resulted in a greater than 50 per cent reduction in $\mathrm{PM}_{10}$. The same study also identified young trees with an open canopy as being very effective at $\mathrm{PM}_{10}$ pollution removal especially when planted as single roadside tree lines, and the authors suggest this configuration as an effective approach to $\mathrm{PM}_{10}$ mitigation rather than arbitrarily enhancing canopy area. As exemplified by the studies of Amorim et al. (2013b; 2013c) and Maher et al. (2013), it is perhaps at the street level next to dwellings where canopy density and planting configuration can have a high impact on daily human exposure to pollution. This is particularly apparent considering urban dwellers can spend up to 90 per cent of their time indoors at home and work (Adgate et al., 2002).

The interaction between the microclimate and the vegetation of street canyons can determine whether the vegetation has a positive or a negative influence on the amount of atmospheric pollution. The complexity of the wind- flow in an urban area is significantly increased by the presence of green infrastructure. Particularly relevant is the modification of the wind vortices that characterize the turbulent recirculation flow between emission sources (buildings, roads and so on) and the vertical exchange rate of pollutants with the upper atmosphere, that is, away from pedestrian-level inhalation. Consequently, local air quality is clearly dependent on the synergies among local meteorological conditions, the three- dimensional configuration of the street canyon and the presence of vegetation. The magnitude of the disruption to vertical airflow induced by trees depends on their morphological characteristics (that is, total height, the crown diameter, the crown-base- height and the leaf area density) and their relative position in the street canyon (that is, the distance to buildings, roads and other trees). In a study by Amorim et al. (2013a), two CFD models, which accounted for the aerodynamics of trees, were applied to selected street canyons in the Portuguese cities of Lisbon and Aveiro. In Lisbon city centre a 12 per cent increase in $\mathrm{CO}$ concentrations was found in the presence of trees, while a general decrease of 16 per cent was obtained in Aveiro. These opposite effects were primarily associated with the different orientation of the street canyon with the incoming wind: nonaligned (c. $\left.45^{\circ}\right)$ in Lisbon and nearly parallel in Aveiro.

\section{Urban Vegetation as a Potential Contributor to Urban Air Pollution}

Plants, and particularly trees, can emit BVOC which can play a critical role in the biosphere-atmosphere interactions and are key factors in the physical and chemical properties of the atmosphere and climate. This is particularly relevant considering the exponential increase of urban population and the increasing attention towards planting programmes in several cities.

Globally an estimated 0.5 to 1.0 billion tonnes of carbon are emitted annually from vegetation as BVOC, dominated by volatile isoprenoids, namely, isoprene $\left(\mathrm{C}_{5} \mathrm{H}_{8}\right)$ and monoterpenes $\left(\mathrm{C}_{10} \mathrm{H}_{16}\right)$ (Guenther et al., 1995). In the presence of nitrogen oxides (NOx), isoprenoids are the main precursors of photochemical ozone $\left(\mathrm{O}_{3}\right)$ production in the troposphere; ozone is a major constituent of summer smog which also seriously compromises plant function. Moreover, BVOC can actively contribute to the formation of ultra- fine particles that aggravate respiratory problems and are particularly dangerous to human health. However, few studies have been carried out to examine the impact of BVOC and this could have important consequences for air quality and pollution episodes in city parks, urban and sub- urban forests, and green belts around industrial conurbations (Niinemets and Peñuelas, 2008; Calfapietra et al. 2013). The realisation of emission inventories is necessary to assess the effects of urban vegetation on presentday air chemistry. For example, Donovan et al., (2005) have produced a classification ranking 30 common urban trees of the UK in terms of BVOC emission. However, the characterization of pollutant 
Tallis MJ, Amorim JH, Calfapietra C, Freer-Smith PH, Grimmond CSB, Kotthaus S, Lemes de Oliveira F, Miranda AI, Toscano P The impacts of green infrastructure on air quality and temperature Handbook on Green Infrastructure: Planning, design and implementation Ed. D Sinnett, $N$ Smith, S Burgess, Chapter 2, 30-49, ISBN: 9781783473991 http://www.e-elgar.com/shop/handbook-on-green-infrastructure

formation, especially ozone, in urban environments is associated with a number of difficulties. In particular, the source strength of BVOC has been difficult to evaluate, and often taxonomy- based inventories used for urban environments (Benjamin et al., 1996; Karlik and Winer, 2001) are overly simplified. This is because the emission potential of even closely related species may vary considerably (Loreto et al., 1998; Kesselmeier and Staudt, 1999). A further problem is that most of the research on emission characteristics has been conducted with native species that mainly dominate the rural areas, natural forests and forest plantations. However, in urban habitats, several, often most, species are exotics (Niinemets and Peñuelas, 2008). While the emission factor databases include information for some of the urban exotic species (for example, Wiedinmyer et al., 2004), reliable information is still lacking for several widespread urban species (Noe et al., 2008). Another problem with quantitative prediction of volatile isoprenoid emissions is that all emission factor databases are based on constitutive emissions (species that are always active in BVOC emission). However, in addition to constitutive emissions, biological and environmental stresses can cause practically every species to be triggered to emit volatiles (inducible emission) (Beauchamp et al., 2005; Niinemets et al., 2010; Toome et al., 2010). Even in several constitutively emitting species, the total emissions (sum of constitutive and induced emissions) can be dominated by induced emissions, for example, the Mediterranean conifer Pinus pinea, often planted in Mediterranean cities (Niinemets et al., 2010). Almost every stress factor can induce BVOC emissions, and recent studies demonstrate that such emissions can make up a large fraction of whole ecosystem fluxes (Karl et al., 2008). Understanding the causes and magnitude of BVOC emissions in urban atmospheres is important for planning (for example, species selection and management) in respect of enhancing air quality.

In summary enhancing the potential for urban vegetation to positively influence urban air quality will depend upon:

- Species type, which influences leaf surface properties, stomatal resistance, leaf form, leaf duration and canopy structure, (for example, Beckett et al., 2000; Sæbø et al., 2012) and the potential for BVOC emissions (for example, Donovan et al., 2005).

- Vegetation size, structure and form, for example, individual tree size and canopy openness are related to the rate of pollution removal. At the extreme, dense planting of street trees leads to the existence of closed canopies over streets. This limits air circulation away from the street and can trap pollution in the street canyon, increasing pedestrian exposure to traffic emitted pollutants. The existence of hedges, green walls, green roofs and herbaceous vegetation need considering as a mechanism to optimise street canyon pollution removal while maintaining effective air circulation.

- Proximity of the vegetation to the pollutant source; the rate of pollution deposition to vegetation generally follows a concentration gradient. This means that the closer the vegetation is to the pollution source then the amount of deposition is increased. However, for the deposition to be sustained in high pollution environments then the vegetation must remain healthy and, therefore, be tolerant of the pollution. More studies are needed in order to identify and evaluate pollution tolerant species mixes.

- Green-space management will also influence the balance between total pollutant uptake (for example, through enhancing vegetation health and leaf area) and pollutant emission by enhancing BVOC release in response to pruning and mowing (Brilli et al., 2012) or indirectly through the emissions associated with processes such as mowing, pruning, irrigation and fertilization (for example, Escobedo et al., 2011). 
Tallis MJ, Amorim JH, Calfapietra C, Freer-Smith PH, Grimmond CSB, Kotthaus S, Lemes de Oliveira F, Miranda AI, Toscano P The impacts of green infrastructure on air quality and temperature Handbook on Green Infrastructure: Planning, design and implementation Ed. D Sinnett, $N$ Smith, S Burgess, Chapter 2, 30-49, ISBN: 9781783473991 http://www.e-elgar.com/shop/handbook-on-green-infrastructure

\section{Urban Vegetation Used for Climate Change Mitigation}

Anthropogenic emissions of greenhouse gases typically include carbon dioxide $\left(\mathrm{CO}_{2}\right)$, methane $\left(\mathrm{CH}_{4}\right)$, nitrous oxide $\left(\mathrm{N}_{2} \mathrm{O}\right)$ but hydrofluorocarbons (HFCs), perflurocarbons (PFCs), sulphur hexafluoride (SF6) and nitrogen trifluoride $\left(\mathrm{NF}_{3}\right)$ which also contribute to climate change (IPCC, 2014). These are regulated under the Kyoto Protocol and Doha Amendment (2012) of the Framework Convention on Climate Change that committed the parties to the convention to reduce the emissions of greenhouse gases. Globally urban areas currently account for 71 to 76 per cent of energy- related $\mathrm{CO}_{2}$ emissions, and as the urban population grows so does the contribution to global emissions (IPCC, 2014).

Vegetation removes $\mathrm{CO}_{2}$ from the atmosphere through the process of photosynthesis. For example, the urban trees of the West Midlands, UK, have been estimated to remove (sequester) 6 per cent of the anthropogenic $\mathrm{CO}_{2}$ emissions from that area (Hewitt et al., n.d.) and the whole urban forest of the USA is estimated to remove approximately 25.6 million tonnes of carbon each year (or $280 \mathrm{~g} \mathrm{C} \mathrm{m}^{-2}$ of tree cover per year) in a carbon removal ecosystem service valued at $\$ 2.0$ billion (Nowak et al., 2013). The rate of carbon sequestration by ornamental lawns (measured in California) was approximately half that of the trees at $140 \mathrm{~g} \mathrm{C} \mathrm{m}^{-2} \mathrm{yr}^{-1}$ (Townsend-Small and Czimczik, 2010) and the range estimated for lawns of the whole USA was between 25.4 and $204.3 \mathrm{~g} \mathrm{C} \mathrm{m}^{-2} \mathrm{yr}^{-1}$; this large range depended on the emissions associated with the intensity of management (Zirkle et al., 2011). However, it should be noted that these grass and tree carbon sequestration rates cannot be considered as direct comparisons owing to differing measurement approaches and assumptions. The next sub-section details a case study examining carbon dioxide removal by urban vegetation in Florence, Italy.

\section{Case Study Investigating the Role of Urban Green Space and Carbon Dioxide Fluxes in Florence, Italy}

Through anthropogenic processes and activities, urban surfaces emit the greenhouse gas $\mathrm{CO}_{2}$. Photosynthesis carried out by urban vegetation can have an important role in removing the $\mathrm{CO}_{2}$ emitted by anthropogenic activities in cities, particularly when vegetation is extensive and/or evergreen. A direct and accurate estimation of carbon uptake by urban vegetation is difficult owing to the particular characteristics of the urban ecosystem and high variability in tree distribution and species. Here, we describe an investigation into the role of urban vegetation in the $\mathrm{CO}_{2}$ fluxes into and out of the city centre of Florence, Italy. Carbon dioxide emissions from the city centre have been measured since 2005 (Matese et al., 2009) and the capacity of urban green spaces to offset the direct anthropogenic $\mathrm{CO}_{2}$ emissions through carbon uptake was calculated.

The Municipality of Florence extends over $102.3 \mathrm{~km}^{2}$, with a total surface area of urban green spaces of $75.7 \mathrm{~km}^{2}$ formed by two main categories: those in densely built- up zones, defined here as 'urban green areas' extending over $29.1 \mathrm{~km}^{2}$, and urban areas of low- density housing extending over $46.6 \mathrm{~km}^{2}$, defined here as 'peri- urban green areas'. In addition to these two main categories, there are also 11541 isolated urban trees, many of which are along avenues and streets. They include 8326 trees, managed directly by the municipality, and 3215 trees under private ownership or owned by other public institutions. The urban green areas can be classified in two main categories: those managed by the municipality $\left(7.7 \mathrm{~km}^{2}\right)$, for which a detailed database of characteristics including tree measurements is available, and those managed by other public and private institutions $\left(21.4 \mathrm{~km}^{2}\right)$. Using the detailed information about the type of green space, species composition and morphometric measurements of the single trees, provided by the municipality, we assigned an annual $\mathrm{CO}_{2}$ uptake factor for each category, 
Tallis MJ, Amorim JH, Calfapietra C, Freer-Smith PH, Grimmond CSB, Kotthaus S, Lemes de Oliveira F, Miranda AI, Toscano P The impacts of green infrastructure on air quality and temperature Handbook on Green Infrastructure: Planning, design and implementation Ed. D Sinnett, $N$ Smith, S Burgess, Chapter 2, 30-49, ISBN: 9781783473991 http://www.e-elgar.com/shop/handbook-on-green-infrastructure

through an analysis of the literature and using the guidelines of the International Panel on Climate Change (IPCC, 2003; 2006). These $\mathrm{CO}_{2}$ uptake factors were then applied and the average $\mathrm{CO}_{2}$ uptake factor per tree determined following the procedure in Vaccari et al. (2013), which was then used to evaluate the total annual $\mathrm{CO}_{2}$ uptake of the urban trees in Florence.

The total urban green spaces of the Municipality of Florence take up $72.5( \pm 18.2) \mathrm{kt} \mathrm{CO}_{2} \mathrm{yr}^{-1}$; of these, $13.5 \mathrm{kt} \mathrm{CO}_{2} \mathrm{yr}^{-1}$ are taken up by the urban green areas, $58.7 \mathrm{kt} \mathrm{CO}_{2} \mathrm{yr}^{-1}$ by the peri-urban green areas; and $0.3 \mathrm{kt} \mathrm{CO}_{2} \mathrm{yr}^{-1}$ by the isolated urban trees. Almost 80 per cent of the total $\mathrm{CO}_{2}$ uptake by the urban green spaces is due to the peri- urban green areas, with a predominant contribution from the orchards, olive trees and grapevines on the hills around the city. Accounting for the inventorial yearly emission database (Trozzi et al., 2009), the total sink of urban green spaces offset 6.2 per cent of the total direct anthropogenic $\mathrm{CO}_{2}$ emissions from Florence, similar to the value of 6 per cent calculated for the West Midlands, UK (Hewitt et al., n.d). In Florence, the urban green areas remove 1.1 per cent of the city's $\mathrm{CO}_{2}$ emissions and 5.1 per cent are removed by the peri-urban green areas (Vaccari et al., 2013).

This procedure was then applied to the green space in a more densely populated and less vegetated 2.1 $\mathrm{km}^{2}$ area city centre location where $\mathrm{CO}_{2}$ fluxes are measured directly using the eddy covariance technique. Here the observed $\mathrm{CO}_{2}$ fluxes from the land surface are always a net source (more $\mathrm{CO}_{2}$ is emitted than removed by the surface) averaging $309( \pm 42) \mathrm{t} \mathrm{CO}_{2} \mathrm{ha}^{-1} \mathrm{yr}^{-1}$ emitted (Gioli et al., 2012). In the flux footprint area $\left(2.1 \mathrm{~km}^{2}\right.$ of a city centre location), the total surface area of urban green space is $0.42 \mathrm{~km}^{2}$ while the total number of trees is 1432 . In this case, the total green areas and trees of the flux footprint area take up $251.4 \mathrm{t} \mathrm{CO}_{2} \mathrm{yr}^{-1}$; of these, $214.2 \mathrm{t} \mathrm{CO}_{2} \mathrm{yr}^{-1}$ are taken up by the urban green areas and $37.2 \mathrm{t} \mathrm{CO}_{2} \mathrm{yr}^{-1}$ by the urban trees. Taking a carbon balance perspective in this city centre location, the total sink from urban green spaces offset 0.4 per cent of the total direct anthropogenic $\mathrm{CO}_{2}$ emissions computed by the eddy covariance method. The city centre of Florence is a source of $\mathrm{CO}_{2}$ where fluxes are entirely governed by anthropogenic emissions, owing to the lack of green space in the flux footprint (Matese et al., 2009). There is a general need to increase knowledge about the role of urban green spaces in offsetting greenhouse gas emissions, in particular using direct measurements of carbon uptake and emissions in urban environments, as recently pointed out by Pataki et al. (2011) and Vaccari et al. (2013).

In summary, it is clear that vegetation can remove $\mathrm{CO}_{2}$ from the atmosphere and the larger the vegetated area the greater is the potential for removal. From two regional studies contrasting in climates and vegetation types (Florence, Italy and the West Midlands, UK) the regional vegetation removed approximately 6 per cent of the regional $\mathrm{CO}_{2}$ emissions, whereas in the densely built city centre of Florence only 0.4 per cent was removed. A balance between building density and land for green space will be crucial in designing urban systems to mitigate urban $\mathrm{CO}_{2}$ emissions and the greening of buildings through the planting of green walls and green roofs could play a role here.

\section{URBAN VEGETATION USED TO MANAGE THE EFFECTS OF INCREASING URBAN TEMPERATURES}

The potential impacts of climate change on urban systems and their populations have heightened concerns over the future sustainability of cities (World Bank, 2010). Urban areas are particularly vulnerable to warming associated with climate change and urban areas warm the local climate relative to the surrounding countryside so exacerbating climate warming locally - an effect called the urban heat island (UHI) (Oke, 1982). For example, during the European heatwave of 2003 night- time urban 
Tallis MJ, Amorim JH, Calfapietra C, Freer-Smith PH, Grimmond CSB, Kotthaus S, Lemes de Oliveira F, Miranda AI, Toscano P The impacts of green infrastructure on air quality and temperature Handbook on Green Infrastructure: Planning, design and implementation Ed. D Sinnett, $N$ Smith, S Burgess, Chapter 2, 30-49, ISBN: 9781783473991 http://www.e-elgar.com/shop/handbook-on-green-infrastructure

temperatures in London peaked at up to $9{ }^{\circ} \mathrm{C}$ higher than surrounding rural areas (GLA, 2006). The European heatwave of 2003 resulted in the deaths of more than 70000 people (Robine et al., 2008) and in France heat- related illnesses were more frequently observed in urban dwellers and the elderly (Dhainaut et al., 2004). Enhanced temperature also increases the potential for ozone and PM pollution; this enhanced pollution contributed to additional deaths in both the UK (Stedman, 2004) and the Netherlands (Fischer et al., 2004). The informed selection and management of green infrastructure can reduce the urban heat island and cool air by between 2 and $8{ }^{\circ} \mathrm{C}$ (Doick and Hutchings, 2013) reducing heat- related stress and the premature deaths associated with high- temperature events.

Green infrastructure modifies micro-climatic conditions and energy consumption across urban areas, with direct benefits for human health and comfort. Impacts on air temperatures result from a complex set of processes that influence different modes of energy exchange (conduction, convection and radiation). Urban surfaces generally absorb and store heat and radiative energy very efficiently owing to their material composition and three- dimensional structure. This results in enhanced warming of the urban atmosphere, so that air temperatures in the centre of a city are often greater (by several degrees) than those in the rural surroundings (Oke, 1982). This UHI effect, is often most pronounced at night because of the slower cooling of urban, compared with rural, surfaces. It may cause air temperatures to reach levels critical for human health (Le Tertre et al., 2006) and thermal comfort (Matzarakis et al., 1999). This may result in greater energy consumption and related pollution emissions where air conditioning and ventilation systems are used (Akbari, 2002).

Most forms and species of vegetation enhance evaporation and generate shadows, both of which act as cooling mechanisms. If water supply is sufficient, evapotranspiration (in addition to heat conduction and ventilation around the plant) ensures that foliage temperatures remain relatively low (Meier and Scherer, 2012). When moisture is added to the atmosphere the air temperature will be lower as the energy is used to evaporate water rather than warm the air. Furthermore, foliage of larger plants such as trees provide extensive shade, thereby reducing the radiation load to areas in their surroundings (Lindberg and Grimmond, 2011). This dampens the rise of surface temperature (Figure 2.2). Health benefits may accrue through reduced exposure to solar and thermal radiation (Thorsson et al., 2014). Shade can also help to reduce cooling- related energy consumption as the building mass will not warm as much as an equivalent building with no shading.

Well- designed green infrastructure can be an effective means of reducing heat stress for urban inhabitants and this is especially important in hot climatic conditions (for example, in the Tropics or during heatwaves). The setting of vegetation within the urban structure is critical (Bowler et al., 2010) and dependent on the location and density of the vegetation; cooling effects extend to different spatial scales. A single, big tree, for example, may beneficially affect the energy balance of one particular building or help to improve the thermal comfort of pedestrians in its immediate vicinity, while the cooling effect of urban parks may extend well beyond the boundaries of the green space (Shashua- Bar and Hoffman, 2000) depending on the structure of the surrounding buildings. Trees providing shade to asphalt or concrete surfaces have a greater direct cooling effect in the area shadowed than those over green spaces. However, street trees are exposed to radiation reflected and emitted by surrounding structures, so typically have higher foliage temperatures than trees in parks and, therefore, must have a good thermal resilience and access to water. For example, a study of 475 urban trees carried out in Basel, Switzerland identified the canopies of street trees to be an average of $1{ }^{\circ} \mathrm{C}$ hotter than park trees (Leuziger et al., 2010). Trees with lower foliage temperature provide a greater cooling effect to their immediate environment than warmer trees, and trees with smaller leaves generally had lower crown 
temperatures than those with larger leaves (Leuziger et al., 2010). Foliage temperature therefore varies with tree species (for example, as function of leaf size) and, in an urban environment, with location, which determines the background meteorological conditions including temperature. For example, in the study by Leuziger et al. (2010) the average temperature of the general urban fabric was approximately $37^{\circ} \mathrm{C}$, the green surfaces the second coolest at $26^{\circ} \mathrm{C}$ and roofs the hottest at $45^{\circ} \mathrm{C}$ (water bodies were the coolest at $18{ }^{\circ} \mathrm{C}$ ). Therefore optimising urban green space for cooling will depend on the choice of species for cooling effects and the temperature regime of the local environment. The amount of water needed to maintain the vegetation and the impact of trees, from their BVOC emissions (discussed in the preceding section), also need consideration. As with the impacts on air quality, the cooling effects of a park on the surroundings also depend on factors such as the nature of the built structures (for example, building heights and street canyon orientation) and meteorological conditions (for example, wind speed and direction). Increasingly, vegetation is being installed on buildings directly, providing shade to walls and roofs as well as insulation to the building. This can reduce conduction through the fabric thus stabilizing indoor temperatures, both in summer and winter. The potential benefits to building energy demand (Kikegawa et al., 2006) depend on the building structure (Castleton et al., 2010). 
Tallis MJ, Amorim JH, Calfapietra C, Freer-Smith PH, Grimmond CSB, Kotthaus S, Lemes de Oliveira F, Miranda AI, Toscano P The impacts of green infrastructure on air quality and temperature Handbook on Green Infrastructure: Planning, design and implementation Ed. D Sinnett, $N$ Smith, S Burgess, Chapter 2, 30-49, ISBN: 9781783473991 http://www.e-elgar.com/shop/handbook-on-green-infrastructure
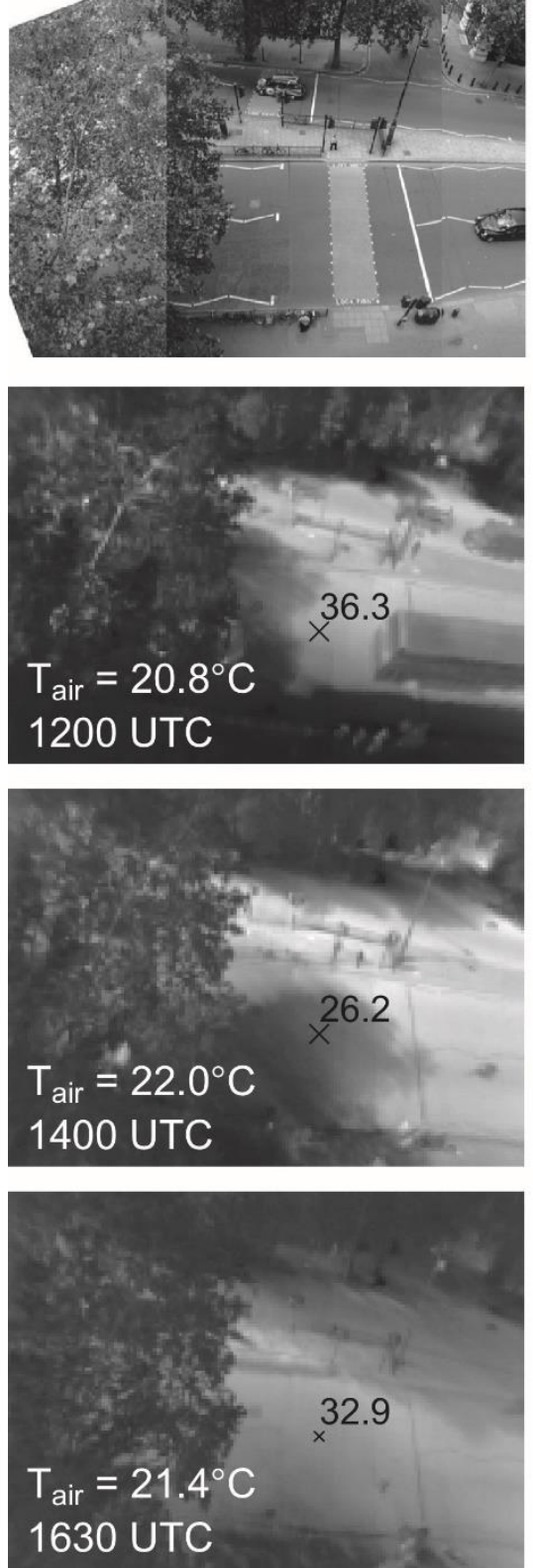

- $19.6 \mathrm{~m}$ a.g.l. - $45.5 \mathrm{~m}$ a.g.l.
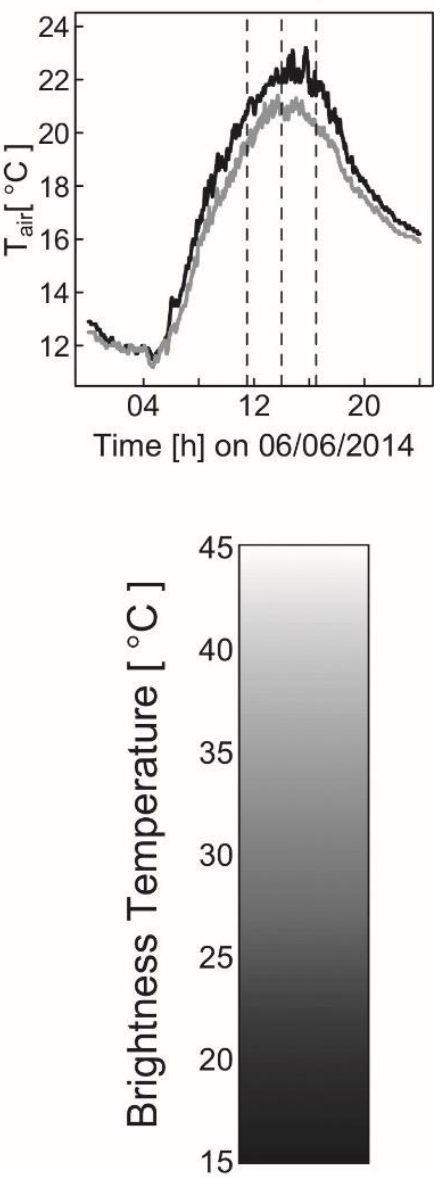

Figure 2.2 Brightness temperature $\left({ }^{\circ} \mathrm{C}\right)$ observed with Optris PI160 thermal imager in a street canyon in central London at three times within a day (6 June 2014). Brightness temperature at one location on the road surface (indicated by $x$ ) is labelled; air temperature (Tair) measured with a WXT520 weather station (Vaisala) at 19.6 (within the urban canyon) and $45.5 \mathrm{~m}$ above ground level $(.2$ mean building height) which is provided for reference. The effects of the trees throughout the day are very clear

\section{LIMITATIONS TO CONSIDER WHEN PLANNING URBAN GREENERY FOR URBAN AIR QUALITY AND TEMPERATURE IMPROVEMENTS}

In terms of removal of urban pollution, there are two major limitations. The first concerns the restricted air re- circulation from the street canyon which may result in greater levels of pollution. The second limitation, which has already been discussed, is the contribution to air pollution from vegetation primarily through BVOC emissions. These limitations can be negated by effective species choice and planting density to allow sufficient air mixing. 
In the case of $\mathrm{CO}_{2}$ removal, the major limitations are the potential area available for urban greening and the emissions generated in managing the vegetation (for example, from maintenance vehicles and machinery and indirectly from fertilizer production and irrigation). The planting area available could be maximised in densely built up areas by planting green walls, green roofs and roadside verges. Emissions could be reduced through adapting management practices and using low maintenance species and planting designs.

With regard to strategies aimed at mitigation of UHI, three limitations need to be considered. First, in the winter, shade from evergreen trees may introduce unwanted cooling effects at low solar elevations (McPherson and Simpson, 2003). Second, tree canopies may trap heat at night (Spronken- Smith and Oke, 1998), enhance humidity and reduce wind flow, so contributing to heat stress. Finally, increasing the area of vegetation will result in increased evaporation (latent heat flux) relative to the turbulent warming of the air (sensible heat flux) and this will reduce the height at which the urban boundary layer forms during the daytime. The urban boundary layer is the internal boundary layer formed when air flows over a city, below this layer the atmosphere is in direct interaction with the surface. The reduction in the height of the boundary layer would mean that a smaller volume of mixed air exists above the surface and this would cause an increase in the concentration of pollutants during the daytime. Knowledge concerning the impacts on air quality associated with how urban greening influences the height of the urban boundary layer is limited. However, a recent study by Terzaghi et al., (2013) identified a 65 per cent increase in $\mathrm{PM}_{10}$ deposition to vegetation during the night- time relative to the daytime. In this study, the increased $\mathrm{PM}_{10}$ deposition resulted from an increase in pollution concentration during the night-t ime. The night-time boundary layer is typically $100 \mathrm{~m}$ above the surface compared with the daytime when the boundary layer can form at circa 2 to $3 \mathrm{~km}$ altitude. So the reduction in temperature could ultimately increase the concentration of some pollutants; a limitations that needs further investigation.

\section{SUMMARY}

Urban vegetation has a positive impact on air quality by reducing the atmospheric concentration of many urban air pollutants that are damaging to health and the environment. Particulate matter is the component of urban air pollution that is most toxic to humans urban and vegetation has been reported to remove between 1 per cent and 60 per cent of PM locally and significantly reduce human exposure. The impacts of urban vegetation on air quality and air temperature depend on many factors, including species, form of the vegetation, location, pollutant type, climatic conditions and urban topography.

When planning urban greening for specific requirements in terms of air quality improvement and temperature regulation then the following generalities may be considered:

1. Typically, pollutants arising from road traffic are best mitigated with well- designed street canyon vegetation that optimises pollution capture while maintaining effective air circulation.

2. Any increase in vegetation cover will benefit atmospheric $\mathrm{CO}_{2}$ removal but this will be enhanced by using vegetation that is low input in terms of resources and management needs. In densely populated areas vegetation area can be enhanced through planting green walls and green roofs were appropriate.

3. Vegetation can be an effective way to reduce the UHI effect through both shade and evaporative cooling of the atmosphere.

4. However, urban vegetation can also be a cause of air pollution directly from BVOC emissions and indirectly from emissions associated with the management of the vegetation. 
Tallis MJ, Amorim JH, Calfapietra C, Freer-Smith PH, Grimmond CSB, Kotthaus S, Lemes de Oliveira F, Miranda AI, Toscano P The impacts of green infrastructure on air quality and temperature Handbook on Green Infrastructure: Planning, design and implementation Ed. D Sinnett, $N$ Smith, S Burgess, Chapter 2, 30-49, ISBN: 9781783473991 http://www.e-elgar.com/shop/handbook-on-green-infrastructure

Well- designed and managed urban vegetation can have a substantial impact on saving lives and money through enhancing air quality and regulating air temperature in the built environment. In addition, green infrastructure can increase water infiltration hence reducing surface run- off and replenishing ground water (see Chapter 3). The beneficial effects of urban vegetation on temperature depend to a considerable extent on the latent heat flux associated with evapotranspiration. The interactions between urban hydrological systems, urban cooling and improved urban air quality illustrate the importance of taking an integrated approach to urban planning.

In short, it is possible to design and manage urban green infrastructure to achieve positive effects on urban air temperatures and air quality and reduce the onward transport of pollutants. This means that architects, planners, engineers and all those involved in green infrastructure management can achieve substantial benefits to the urban environment by the effective use of vegetation.

ACKNOWLEDGEMENTS: The authors would like to thank Christine Hughes and Professor Simon Cragg for the scanning electron microscope image, Alex McMahon for quantifying PM deposition to London Plane leaves, and Dr John Peterkin for proof reading this chapter (all from the University of Portsmouth, 2014). The observations in Figure 2.2 were supported by NERC ClearfLo.

\section{REFERENCES}

Adgate, J.L., Ramachandran, G., Pratt, G.C., Waller, L.A. and Sexton, K. (2002), 'Spatial and temporal variability in outdoor, indoor, and personal PM2.5 exposure', Atmospheric Environment, 36 (20), 3255-65.

Akbari, H. (2002), 'Shade trees reduce building energy use and $\mathrm{CO}_{2}$ emissions from power plants', Environmental Pollution, 116 (supplement 1 March), S119-S126.

Amorim J.H., Rodrigues, V., Tavares, T., Valente, J. and Borrego, C. (2013c), 'CFD modelling of the aerodynamic effect of trees on urban air pollution dispersion', Science of the Total Environment, 461 (September), 541-51.

Amorim J.H., Valente, J., Cascão, P., Pimentel, C., Miranda, A.I. and Borrego, C. (2013a), 'Pedestrian exposure to air pollution in cities: modelling the effect of roadside trees', Advances in Meteorology, art. ID 964904, 7.

Amorim, J.H., Valente, J., Pimentel, C., Cascão, P., Rodrigues, V., Miranda, A.I. and Borrego, C. (2013b), 'Modeling the role of urban green infrastructures on students' exposure to traffic-r elated air pollution', in K.C. Lee (ed.), Recent Advances in Urban Planning and Construction. Proceedings of the Fourth International Conference on Urban Sustainability, Cultural Sustainability, Green Development, Green Structures and Clean Cars (USCUDAR '13), Proceedings of the First WSEAS International Conference on High- Performance Concrete Structures and Materials (COSTMA '13), Budapest, 10-12 December, WSEAS Press.

Ashworth, W. (1954), The Genesis of Modern British Town Planning: A Study in Economic and Social History of the Nineteenth and Twentieth Centuries, London: Routledge \& Kegan Paul.

Beauchamp J., Wisthaler, A., Hansel, A., Kleist, E., Miebach, M., Niinemets, Ü., Schurr, U. and Wildt, J. (2005), 'Ozone induced emissions of biogenic VOC from tobacco: relations between ozone uptake and emission of LOX products', Plant, Cell and Environment, 28 (10), 1334-43.

Beckett, P.K., Freer-Smith, P.H. and Taylor, G. (2000), 'Effective tree species for local air-quality management', Journal of Arboriculture, 26 (1), 12-18.

Beevers, S.D., Kitwiroon, N., Williams, M.L., Kelly, F.J., Anderson, H.R. and Carslaw, D.C. (2013), 'Air pollution dispersion models for human exposure predictions in London', Journal of Exposure Science and Environmental Epidemiology, 23 (6), 647-53.

Benedict, M.A. and McMahon, E.T. (2006), Green Infrastructure: Linking Landscapes and Communities, Washington, DC: Island Press.

Benjamin, M.T., Sudol, M., Bloch, L. and Winer, A.M. (1996), 'Low- emitting urban forests: a taxonomic methodology for assigning isoprene and monoterpene emission rates', Atmospheric Environment, 30 (9), 1437-52.

Bowler, D., Buyung- Ali, E.L., Knight, T.M. and Pullin, A.S. (2010), 'Urban greening to cool towns and cities: a systematic review of the empirical evidence', Landscape and Urban Planning, 97 (3), 147-55.

Brilli, F., Hörtnagl, L., Bamberger, I., Schnitzhofer, R., Ruuskanen, T.M., Hansel, A., Loreto, F. and Wohlfahrt, G. (2012), 'Qualitative and quantitative characterization of volatile organic compound emissions from cut grass', Environmental Science \& Technology, 46 (7), 3859-65.

Brito, F.F, Gimeno, P.M., Martínez, C., Tobías, A., Suárez, L., Guerra, F., Borja, J.M. and Alonso, A.M. (2007), 'Air pollution and seasonal asthma during the pollen season. A cohort study in Puertollano and Ciudad Real (Spain)', Allergy, 62 (10), $1152-$ 7. 
Tallis MJ, Amorim JH, Calfapietra C, Freer-Smith PH, Grimmond CSB, Kotthaus S, Lemes de Oliveira F, Miranda AI, Toscano P The impacts of green infrastructure on air quality and temperature Handbook on Green Infrastructure: Planning, design and implementation Ed. D Sinnett, $N$ Smith, S Burgess, Chapter 2, 30-49, ISBN: 9781783473991 http://www.e-elgar.com/shop/handbook-on-green-infrastructure

Caiazzo, F, Ashok, A., Waitz, I.A., Yim, S.H.L. and Barrett, S.R.H. (2013), 'Air pollution and early deaths in the United States. Part I: Quantifying the impact of major sectors in 2005', Atmospheric Environment, 79 (November), 198-208.

Calfapietra, C., Fares, S., Manes, F., Morani, A., Sgrigna, G. and Loreto, F. (2013), 'Role of biogenic volatile organic compounds (BVOC), emitted by urban trees on ozone concentration in cities: a review', Environmental Pollution, 183 (December), 71-80.

Castleton, H., Stovin, F.V., Beck, S.B.M. and Davison, J.B. (2010), 'Green roofs; building energy savings and the potential for retrofit', Energy and Buildings, 42 (10), 1582-91.

Chadwick, G. (1966), The Park and the Town: Public Landscape in the 19th and 20th Centuries, London: Architectural Press.

Cherry, G. (1974), The Evolution of British Town Planning: A History of Town Planning in the United Kingdom During the 20th Century and of the Royal Town Planning Institute, 1914-74, New York: John Wiley and Sons.

Commission of the European Communities (CEC) (2008), Directive 2008/50/EC of the European Parliament and of the Council of 21 May 2008 on ambient air quality and cleaner air for Europe. Official Journal of the European Union, L152, 1-44, available at: http://eur-1 ex.europa.eu/legal- content/EN/ TXT/?uri5CELEX:32008L0050 (accessed 24 June 2015).

Department for Environment, Food and Rural Affairs (DEFRA) (2010), Air Pollution: Action in a Changing Climate, available at: https://www.gov.uk/government/publications/air- pollution- action- in- a- changing- climate (accessed 20 November 2014).

Doick, K. and Hutchings, T. (2013), 'Air temperature regulation by urban trees and green infrastructure', Forestry Commission Research Note 12, pp. 1-10, available at: http://www.forestry.gov.uk/pdf/FCRN012. pdf/\$FILE/FCRN012.pdf (accessed 20 November 2014).

Donovan, R.G., Stewart, H.W., Owen, S.M., Mackenzie, A.R. and Hewitt, C.N. (2005), 'Development and application of an urban tree air quality score for photochemical pollution episodes using the Birmingham, United Kingdom, area as a case study', Environmental Science \& Technology, 39 (17), 6730-38.

Escobedo, F.J., Kroeger, T. and Wagner, J.E. (2011), 'Urban forests and pollution mitigation: analyzing ecosystem services and disservices', Environmental Pollution, 159 (8), 2078-87.

Fantozzi, F., Monaci, F., Blanusa, T. and Bargagli, R. (2013), 'Holm Oak (Quercus ilex L.), canopy as interceptor of airborne trace elements and their accumulation in the litter and topsoil', Environmental Pollution, 183 (December), 89-95.

Fischer, P.H., Brunekreef, B. and Lebret, E. (2004), 'Air pollution related deaths during the 2003 heat wave in the Netherlands', Atmospheric Environment, 38 (8), 1083-85.

Fowler, D., Cape, T.N. and Unsworth, M.H. (1989), 'Deposition of atmospheric pollutants on forests', Philosophical Transactions of the Royal Society of London, 324 (August), 247-65.

Freer-S mith, P.H., Beckett, K.P. and Taylor, G. (2005), 'Deposition velocities to Sorbus aria, Acer campestre, Populus deltoides X trichocarpa "Beaupre", Pinus nigra and Cupressocyparis leylandii for coarse, fine and ultra- fine particles in the urban environment', Environmental Pollution, 133 (1), 157-67.

Gioli, B., Toscano, P., Lugato, E., Matese, A., Miglietta, F., Zaldei, A. and Vaccari, F.P. (2012), 'Methane and carbon dioxide fluxes and source partitioning in urban areas: the case study of Florence, Italy', Environmental Pollution, 164 (May), $125-31$.

Greater London Authority (GLA) (2006), London's Urban Heat Island: A Summary for Decision Makers. London: Greater London Authority.

Guenther, A., Hewitt, C.N., Erickson, D., Fall, R., Geron, C., Graedel, T., Harley, P., Klinger, L., Lerdau, M., McKay, M.A., Pierce, T., Scholes, B., Steinbrecher, R., Tallamraju, R., Taylor, J., and Zimmerman, P. (1995), 'A global model of natural volatile organic compound emissions', Journal of Geophysical Research: Atmospheres (1984-2012), 100 (D5), $8873-92$.

Hewitt, N., H. Stewart, R. Donovan and R. MacKenzie (n.d.), 'Trees and sustainable urban air quality', available at: http://www.es.lancs.ac.uk/people/cnh/docs/UrbanTrees.htm (accessed 20 November 2014).

House of Commons (2010), Air Quality - Environmental Audit Committee. 5th Report, 2009-10, available at http://www.publications.parliament.uk/pa/cm200910/cmselect/cmenvaud/229/22902.htm (accessed 20 November 2014).

Howard, E. (1898), To-M orrow: A Peaceful Path to Real Reform, London: Swan Sonnenschein \& Co. Ltd.

International Panel on Climate Change (IPCC) (2003), Good Practice Guidance for LULUCF (Land Use, Land Use Change and Forestry), available at: http://www.ipcc- nggip.iges.or.jp/public/gpglulucf/gpglulucf.html (accessed 18 November 2014).

International Panel on Climate Change (IPCC) (2006), Guidelines for National Greenhouse Gas Inventories. AFOLU (Agriculture, Forestry and Other Land Use), available at: http://www.ipcc-n ggip.iges.or.jp/ public/2006gl/vol4.html (accessed 18 November 2014).

International Panel on Climate Change (IPCC) (2014), Summary for Policymakers, in O. Edenhofer, O., Pichs- Madruga, R., Sokona, Y., Farahani, E., Kadner, S., Seyboth, K., Adler, A., Baum, I., Brunner, S., Eickemeier, P., Kriemann, B., Savolainen, J., Schlömer, S., von Stechow, C., Zwickel, T. and Minx, J.C. (eds), Climate Change 2014: Mitigation of Climate Change. Contribution of Working Group III to the Fifth Assessment Report of the Intergovernmental Panel on Climate Change, Cambridge and New York: Cambridge University Press.

Karl, T., Guenther, A., Turnipseed, A., Patton, E.G. and Jardine, K. (2008), 'Chemical sensing of plant stress at the ecosystem scale', Biogeosciences, 5 (May), 1287-94.

Karlik J.F. and Winer, A.M. (2001), 'Measured isoprene emission rates of plants in California landscapes: comparison to estimates from taxonomic relationships', Atmospheric Environment, 35 (6), 1123-31.

Kesselmeier, J. and Staudt, M. (1999), 'Biogenic volatile organic compounds (VOC): an overview on emission, physiology and ecology', Journal of Atmospheric Chemistry, 33, $23-88$.

Kikegawa, Y., Genchi, Y., Kondo, H. and Hanaki, K. (2006), 'Impacts of city-b lock- scale countermeasures against urban heatisland phenomena upon a building's energy-c onsumption for air- conditioning', Applied Energy, 83 (6), 649-68.

Kim, J.J., Huen, K., Adams, S., Smorodinsky, S., Hoats, A., Malig, B., Lipsett, M. and Ostro, B. (2008), 'Residential traffic and children's respiratory health', Environmental Health Perspectives, 116 (9), 1274-79. 
Tallis MJ, Amorim JH, Calfapietra C, Freer-Smith PH, Grimmond CSB, Kotthaus S, Lemes de Oliveira F, Miranda AI, Toscano P The impacts of green infrastructure on air quality and temperature Handbook on Green Infrastructure: Planning, design and implementation Ed. D Sinnett, $N$ Smith, S Burgess, Chapter 2, 30-49, ISBN: 9781783473991 http://www.e-elgar.com/shop/handbook-on-green-infrastructure

Le Tertre, A., Lefranc, A., Eilstein, D., Declercq, C., Medina, S., Blanchard, M., Chardon, B. Fabre, P., Filleul, L., Jusot, JF., Pascal, L., Prouvost, H., Cassadou, S., and Ledrans, M.,. (2006), 'Impact of the 2003 heatwave on all- cause mortality in 9 French cities', Epidemiology, 17 (1), 75-9.

Lemes de Oliveira, F. (2014), 'Green wedges: origins and development in Britain', Planning Perspectives, 29 (3), $357-79$.

Leuziger, S., Vogt, R., Ateya, O. and Körner, C. (2010), 'Tree surface temperature in an urban environment', Agricultural and Forest Meteorology, 150 (1), 56-62.

Lindberg, F. and Grimmond, C.S.B. (2011), 'The influence of vegetation and building morphology on shadow patterns and mean radiant temperatures in urban areas: model development and evaluation', Theoretical and Applied Climatology, 105 (3-4), $311-23$.

Loreto, F., Ciccioli, P., Brancaleoni, E., Valentini, R., De Lillis, M., Csiky, O. and Seufert, G. (1998), 'A hypothesis on the evolution of isoprenoid emission by oaks based on the correlation between emission type and Quercus taxonomy', Oecologia, 115 (3), 302-5.

Lovett, G.M. (1994), 'Atmospheric deposition of nutrients and pollutants in North America: an ecological perspective', Ecological Applications, 4 (4), 629-50.

Maher, B.A., Ahmed, I.A.M., Davison, B., Karloukovski, V. and Clarke, R. (2013), 'Impact of roadside tree lines on indoor concentrations of traffic- derived particulate matter', Environmental Science \& Technology, 47 (23), 13737-44.

Matese, A., Gioli, B., Vaccari, F.P., Zaldei, A. and Miglietta, F. (2009), 'Carbon dioxide emissions of the city center of Firenze, Italy: measurement, evaluation, and source partitioning', Journal of Applied Meteorology and Climatology, 48 (9), $1940-47$.

Matzarakis, A., Mayer, H. and Iziomon, M.G. (1999), 'Applications of a universal thermal index: physiological equivalent temperature', International Journal of Biometeorology, 43, 76-84.

McPherson, E.G. and Simpson, J.R. (2003), 'Potential energy savings in buildings by an urban tree planting programme in California', Urban Forestry \& Urban Greening, 2 (2), 73-86.

Meier, F. and Scherer, D. (2012), 'Spatial and temporal variability of urban tree canopy temperature during summer 2010 in Berlin, Germany', Theoretical and Applied Climatology, 110 (3), 373-84.

McPherson, E.G., Nowak, D.J. and Rowntree, R.A. (1994), 'Chicago's urban forest ecosystem: results of the Chicago Urban Forest Climate Project', US Department of Agriculture, Forest Service, Northeastern Forest Experiment Station, Radnor, PA available at: http://www.nrs.fs.fed.us/pubs/gtr/gtr_ne186.pdf (accessed 24 June 2015).

Niinemets, Ü. and Peñuelas, J. (2008), 'Gardening and urban landscaping: significant players in global change', Trends in Plant Science, 13 (2), 60-65.

Niinemets, Ü., Monson, R.K., Arneth, A., Ciccioli, P., Kesselmeier, J., Kuhn, U., Noe, S.M., Peñuelas, J. and Staudt, M. (2010), 'The leaf- level emission factor of volatile isoprenoids: caveats, model algorithms, response shapes and scaling', Biogeosciences, 7 (6), 1809-32.

Noe, S.M.,Peñuelas, J. and Niinemets, U. (2008), 'Monoterpene emissions from ornamental trees in urban areas: a case study of Barcelona, Spain', Plant Biology, 10 (1), 163-9.

Nowak, D.J., Crane, D.E. and J.C. Stevens (2006), 'Air pollution removal by urban trees and shrubs in the United States', Urban Forestry \& Urban Greening, 4 (3), 115-23.

Nowak, D.J., Crane, D.E., Stevens, J.C. and Ibarra, M. (2002), Brooklyn's Urban Forest, USDA Forest Service General Technical Report, Newtown Square, PA: USDA Forest Service.

Nowak, D.J., Greenfield, E.J., Hoehn, R.E. and Lapoint, E. (2013), 'Carbon storage and sequestration by trees in urban and community areas of the United States', Environmental Pollution, 178 (July), 229-36.

Oke, T.R. (1982), 'The energetic basis of the Urban Heat Island', Quarterly Journal of the Royal Meteorological Society, 108 (455), 1-24.

Pataki, D.E., Carreiro, M.M., Cherrier, J., Grulke, N.E., Jennings, V. and Pincetl, S. (2011), 'Coupling biogeochemical cycles in urban environments: ecosystem services, green solutions, and misconceptions', Frontiers Ecology Environment, 9 (1), 27 36.

Peachey, C.J., Sinnett, D., Wilkinson, M., Morgan, G.W., Freer- Smith, P.H. and Hutchings, T.R. (2009), 'Deposition and solubility of airborne metals to four plant species grown at varying distances from two heavily trafficked roads in London', Environmental Pollution, 157 (8), 2291-9.

Pryor, S.C., Gallagher, M., Sievering, H., Larsen, S.E., Barthelmie, R.J., Birsan, F., Nemitz, E., Rinne, J., Kulmala, M., Grönholm, T., Taipale, R. and Vesala, T. (2008), 'A review of measurement and modelling results of particle atmosphere-surface exchange', Tellus $B, 60$ (1), 42-75.

Pugh, T.A.M., MacKenzie, A.R., Whyatt, J.D. and Hewitt, C.N. (2012), 'Effectiveness of green infrastructure for improvement of air quality in urban street canyons', Environmental Science \& Technology, 46 (14), 7692-9.

Robine, J.- M., Cheung, S.L.K., Le Roy, S., Van Oyen, H., Griffiths, C., Michel, J.-P . and Herrmann, F.R. (2008), 'Death toll exceeded 70,000 in Europe during the summer of 2003', Comptes Rendus Biologies, 331 (2), 171-8.

Roupsard, P., Amielh, M., Maro, D., Coppalle, A., Branger, H., Connan, O., Laguionie, P., Hébert, D. and Talbaut, M. (2013), 'Measurement in a wind tunnel of dry deposition velocities of submicron aerosol with associated turbulence onto rough and smooth urban surfaces', Journal of Aerosol Science, 55 (January), 12-24.

Sæbo, A., Popek, R., Nawrot, B., Hanslin, H.M., Gawronska, H., and Gawronski, S.W. (2012), 'Plant species differences in particulate matter accumulation on leaf surfaces', Science of the Total Environment, 427 (June), 348-9.

Shashua- Bar, L. and Hoffman, M.E. (2000), 'Vegetation as a climatic component in the design of an urban street', Energy and Buildings, 31 (3), 221-35. 
Tallis MJ, Amorim JH, Calfapietra C, Freer-Smith PH, Grimmond CSB, Kotthaus S, Lemes de Oliveira F, Miranda AI, Toscano P The impacts of green infrastructure on air quality and temperature Handbook on Green Infrastructure: Planning, design and implementation Ed. D Sinnett, $N$ Smith, S Burgess, Chapter 2, 30-49, ISBN: 9781783473991 http://www.e-elgar.com/shop/handbook-on-green-infrastructure

Spronken- Smith, R.A., and Oke, T.R. (1998), 'The thermal regime of urban parks in two cities with different summer climates', International Journal of Remote Sensing, 19 (11), 2085-104.

Stedman, J.R. (2004), 'The predicted number of air pollution related deaths in the UK during the August 2003 heatwave', Atmospheric Environment, 38 (8), 1087-90.

Sutcliffe, A. (1981), British Town Planning: The Formative Years, Leicester: Leicester University Press.

Tallis, M., Taylor, G., Sinnett, D. and Freer- Smith, P.H. (2011), 'Estimating the removal of atmospheric particulate pollution by the urban tree canopy of London, under current and future environments', Landscape and Urban Planning, 103 (2), 129-38.

Terzaghi, E., Wild, E., Zacchello, G., Cerabolini, B.E.L., Jones, K.C. and Di Guardo, A. (2013), 'Forest filter effect: role of leaves in capturing/releasing air particulate matter and its associated PAHs', Atmospheric Environment, 74 (August), 378-84.

Thorsson, S., Rocklöv, J., Konarska, J., Lindberg, F., Holmer, B., Dousset, B. and Rayner, D. (2014), 'Mean radiant temperature - a predictor of heat related mortality', Urban Climate, 10, pt 2 (December), 332-45.

Toome, M., Randjärv, P., Copolovici, L., Niinemets, Ü., Heinsoo, K., Luik, A. and Noe, S.M. (2010), 'Leaf rust induced volatile organic compounds signalling in willow during the infection', Planta, 232 (1), 235-43.

Townsend- Small, A. and Czimczik, C.I. (2010), 'Carbon sequestration and greenhouse gas emissions in urban turf', Geophysical Research Letters, 37 (2), January 2010.

Trozzi, C., Cervella, M., Di Cristofaro, E., Piscitello, E., Villa, S. (2009), 'Inventario delle Emissioni di inquinanti dell'aria e modellistica per la valutazione della qualità dell'aria allo stato attuale e in proiezione. Allegato 1 - Inventario regionale delle sorgenti di emissioni IRSE 1995- 2007' ('Air pollutants emission inventory and modelling for the evaluation of air quality for present and future scenario. Chapter 1 - The official regional emission inventory IRSE 1995-2007'), Techne Consulting, report RF- A1, Rome. (In Italian)

Vaccari, F.P., Gioli, B., Toscano, P. and Perrone, C. (2013), 'Carbon dioxide balance assessment of the city of Florence (Italy), and implications for urban planning', Landscape and Urban Planning, 120 (December), 138-46.

Weber, F., Kowarik, I. and Säumel, I. (2014), 'Herbaceous plants as filters: immobilization of particulates along urban street corridors', Environmental Pollution, 186 (March), 234-40.

Wiedinmyer, C., Guenther, A., Harley, P., Hewitt, C.N., Geron, C., Artaxo, P., Steinbrecher, R. and Rasmussen, R. (2004), 'Global organic emissions from vegetation', in C. Granier, P. Artaxo and C.E. Reeves (eds), Emissions of Atmospheric Trace Compounds, Dordrecht: Kluwer Academic, pp. 115-70.

World Bank (2010), Cities and Climate Change: An Urgent Agenda, available at: http://go.worldbank.org/ FMZQ8HVQJ0 (accessed 20 November 2014).

World Health Organization (WHO) (2006), WHO Air Quality Guidelines for Particulate Matter, Ozone, Nitrogen Dioxide and Sulfur Dioxide Global Update 2005, available at: http://whqlibdoc.who.int/hq/2006/ WHO_SDE_PHE_OEH_06.02_eng.pdf (accessed 20 November 2014).

World Health Organization (WHO) (2013), Health Effects of Particulate Matter Policy Implications for Countries in Eastern Europe, Caucasus and central Asia, available at http://www.euro.who.int/_data/assets/pdf_file/0006/189051/Health- effectsof- particulate- matter- final- Eng.pdf (accessed 20 November 2014).

World Health Organization (WHO) (2014), Mortality from Ambient Air Pollution: Situation and Trends, available at: http://www.who.int/gho/phe/outdoor_air_pollution/burden_text/en/ (accessed 20 November 2014).

Zhu, T., Melamed, M.L., Parrish, D., Gauss, M., Klenner. L.G., Lawrence, M., Konare, A. and Liousse, C. (2013), 'WMO/IGAC impacts of megacities on air pollution and climate', available at: http://www.wmo.int/ pages/prog/arep/gaw/gaw- reports.html (accessed 20 November 2014).

Zirkle, G., Lal, R. and Augustin, B. (2011), 'Modeling carbon sequestration in home lawns', HortScience, 46 (5), 808-14. 